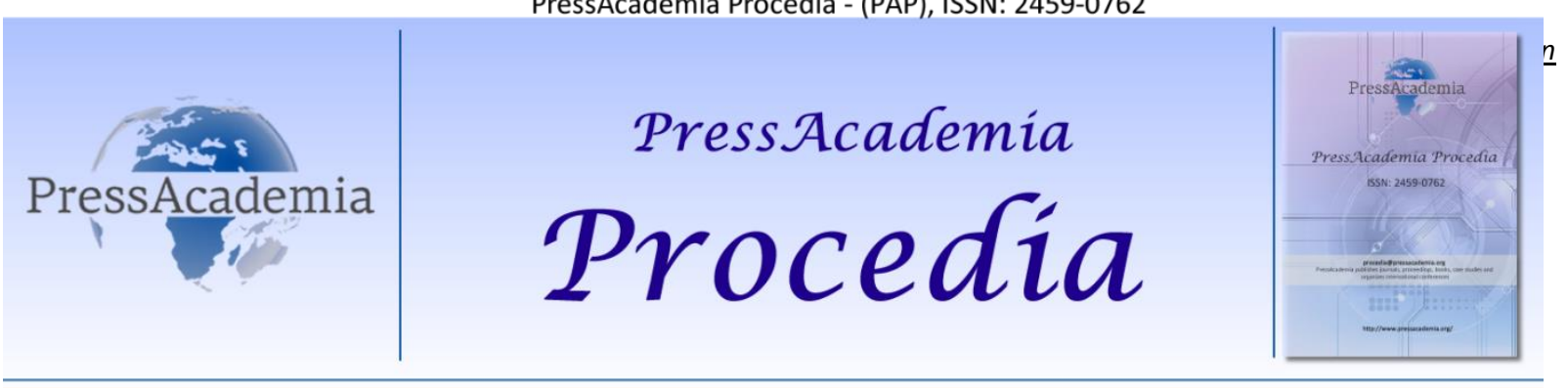

2nd World Conference on Technology, Innovation and Entrepreneurship

May 12-14, 2017, Istanbul, Turkey. Edited by Sefer Şener

\title{
DESIGN OF ZIGBEE BASED WIRELESS ONLINE MONITORING SYSTEM FOR PHOTOVOLTAIC POWER SYSTEMS
}

DOI: 10.17261/Pressacademia.2017.578

PAP-WCTIE-V.5-2017(16)-p.102-110

Hakan Bogan ${ }^{1}$

${ }^{1}$ Ege University, hb@hakanbogan.com

\begin{abstract}
Within this project, it is intended to design and implement a web-based wireless photovoltaic monitoring system that can measure important parameters for photovoltaic power systems and perform performance calculations and comparisons of the modules. A webbased, low-cost wireless monitoring system using the Zigbee wireless communication protocol has been developed, taking into account the International Electrotechnical Commission (IEC) standards. Thanks to this developed Zigbee based monitoring system, the data in the power plant can be recorded without any loss without regard to weather conditions. It also has the necessary infrastructure for various emergency scenarios. At this point, the investor can access the system from any device with internet access, regardless of where in the world. As a result of the tests made, there is no data loss between the receiver and the transmitter in this developed system. Emergency systems, which are developed as solutions to electricity or internet interruption problems, prevent data losses.
\end{abstract}

Keywords: Zigbee, photovoltaic, monitoring, online, wireless sensors network.

\section{INTRODUCTION}

As the energy demand on the world increases with the growing world population, all countries attach great importance to the development of renewable energy day by day. People consider that the solar energy is most reliable and promising energy source among the renewable energy sources (Shariff, Rahim \& Ping, 2015). There are many photovoltaic power plants that need to be managed and kept healthy state of these power plants by using information techniques. That is important point that needs to be dealt with for controlled and successful electricity generation (TaoHua, Zhenga, Tana, Zhua \& Miao, 2015)

The Compound Annual Growth Rate (CAGR) of Photovoltaic installations was $42 \%$ between 2000 to 2015. Concerning PV module production in 2015, China\&Taiwan hold the lead with a share of $67 \%$, followed by Rest of Asia-Pacific \& Central Asia (ROAP/CA) with 14\%. Europe contributed with a share of $5 \%$ (was 6\% in 2014); USA/CAN contributed $3 \%$. In 2015, Europe's contribution to the total cumulative PV installations amounted to $40 \%$ (compared to $48 \%$ in 2014). In contrast, installations in China accounted for $21 \%$ (compared to $17 \%$ in 2014)(Philipps \& Warmuth, 2016).

The total installed capacity of 1078 Photovoltaic Power Plants located in Turkey is 860,63 MW. In 2016, 1,020,000,000 kilowatt-hours of electricity generation was made with Photovoltaic Power Plants (Güneş Enerji Santralleri, n.d.). Turkey is a growing market with so much acceleration. It has the potential to become a leader in the world with accurate and conscious guidance.

Some environmental and electrical factors such as dust, dirt, bird droppings, weather conditions and accidents can reduce energy generation efficiency. Therefore, photovoltaic plant and power generation should be kept under constant surveillance. Constantly monitoring the system makes it possible to identify problems instantly and enables early intervention. So total production will be kept at the highest level (Woyte et al., 2013).

Wireless communication is used to facilitate data transmission in monitoring systems. Various types of wireless technology and networks allow devices to speak (send data) to each other and to the web (TCP/IP Networks) without cables. There are 
many wireless communication protocols such as Bluetooth, ZigBee, WiFi and LTE used for wireless communication. Each protocol has its own advantages and areas of usage.

ZigBee is a wireless technology developed as an open global standard to address the unique needs of low-cost, low-power wireless Machine to Machine (M2M) networks. The ZigBee standard operates on the IEEE 802.15.4 physical radio specification and operates in unlicensed bands including $2.4 \mathrm{GHz}, 900 \mathrm{MHz}$ and $868 \mathrm{MHz}$. ZigBee enables broad-based deployment of wireless networks with low-cost, low-power solutions. It provides the ability to run for years on inexpensive batteries for a host of monitoring and control applications. Smart energy/smart grid, AMR (Automatic Meter Reading), lighting controls, building automation systems, tank monitoring, HVAC control, medical devices and fleet applications are just some of the many spaces where ZigBee technology is making significant advancements (XBee and XBee Pro, n.d.)

The analysis of photovoltaic power plants is made in the framework of the parameters determined in IEC 61724 standards and the necessary calculations are carried out. Wireless photovoltaic monitoring system using the Zigbee wireless communication protocol has been developed in this project, taking into account the International Electrotechnical Commission (IEC) standards.

\section{LITERATURE REVIEW}

In the past there are works related to data transfer and recording in photovoltaic power plants. Various monitoring systems were introduced and released. It seems that nowadays it is still necessary to develop the technology and reduce the costs in photovoltaic systems (Katsioulis, n.d.). Information about the data transfer technologies used in these studies can be found below.

\subsection{Data Transfer}

Past studies have been done in two ways as wired and wireless. RS232 or RS484 cables were generally used in wired systems and they are computer based (Anwari, Dom, \& Rashid, 2011; Ayompe, Duffy, McCormack, \& Conlon, 2011). Wired monitoring systems are not preferred because of their limitations and various negative aspects (Shariff, Rahim \& Ping, 2015).

Monitoring systems include devices with various wireless data transfer technologies such as satellite (Krauter, 2004), GSM (Gagliarducci, Lampasi, \& Podestà, 2007; Rosiek \& Batlles, 2008) and ZigBee (Shariff, Rahim \& Ping, 2015; Katsioulis, Karapidakis, Hadjinicolaou \& Tsikalakis, 2011). Satellite technology has a high installation cost. Despite this, the data transmission speed is very low (Krauter, 2004). GSM is a really secure technology. Data transmission rate of GSM is approximate $100 \%$. However, this technology has high operating costs (Rosiek \& Batlles, 2008). Bluetooth may be a good alternative, but this technology has a short transmission range (Hua, Lin, Xu, Li, \& Ouyang, 2009). Wi-Fi has very high data rate. However, cost and power consumption of this technology is high when compared to other technologies such as Bluetooth and ZigBee (López, Mantiñan \& Molina, 2012). ZigBee has low data transfer rate when compared to others. However, it has huge network size, long range capacity, low power consumption and reliability (Shariff, Rahim \& Ping, 2015). Therefore, ZigBee is popular.

\section{DATA AND METHODOLOGY}

\subsection{Parameters}

The International Electrotechnical Commission (IEC) is a worldwide organization for standardization comprising all national electrotechnical committees (IEC National Committees). IEC promotes international co-operation on all questions concerning standardization in the electrical and electronic fields. To this end and in addition to other activities, IEC publishes International Standards, technical Specifications, Technical Reports, Publicly Available Specifications (PAS) and Guides.

Today, large investments are made in photovoltaic power plants. Monitoring these investments and production of plants is of great importance. It is necessary to make a conscious measurement taking into account the parameters to be measured specified in IEC 61724 standards. 
Figure 1: The parameters to be Measured in Real Time
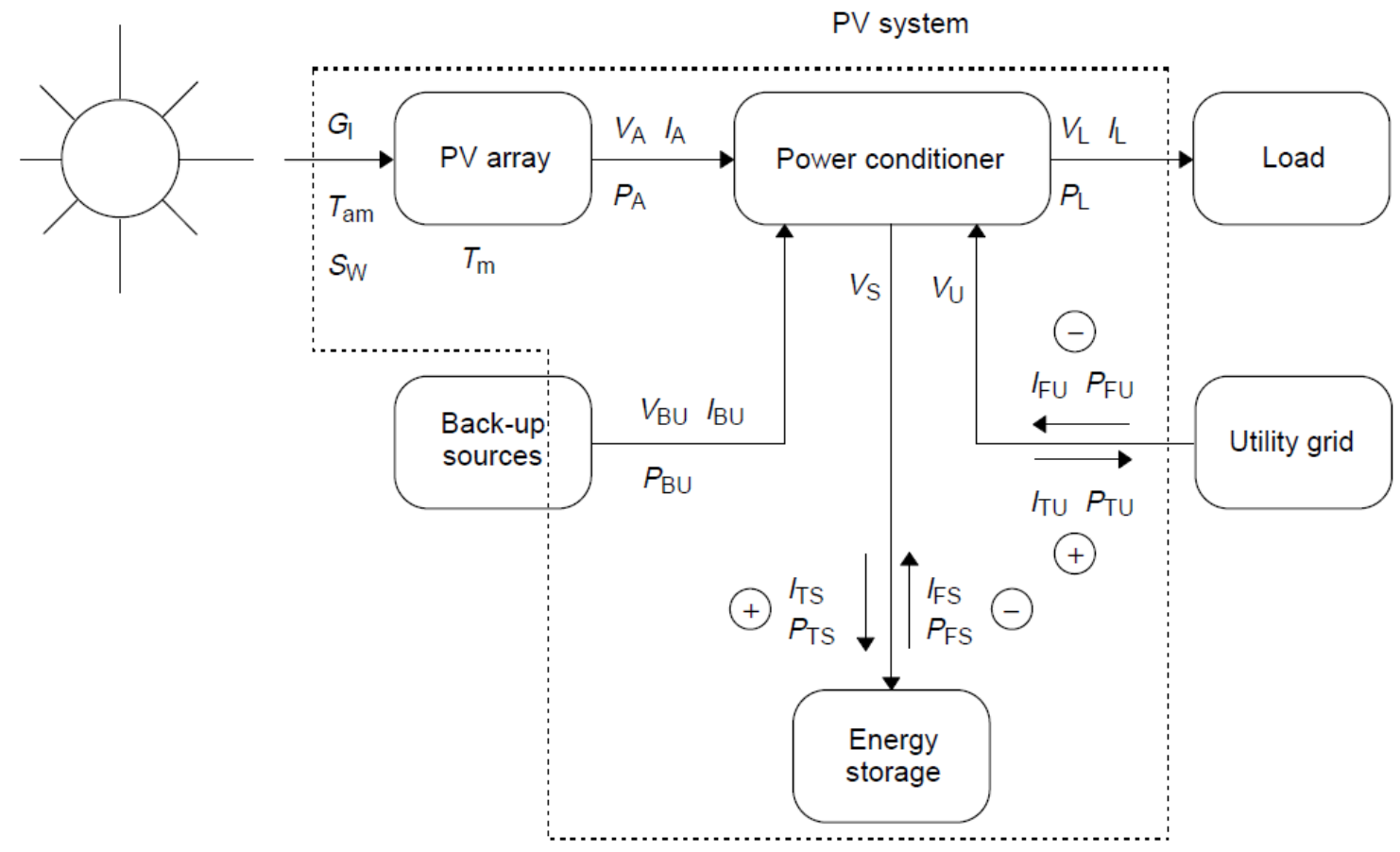

IEC $516 / 98$

\subsection{Materials and Equipment}

\subsubsection{Sensors}

Some parameters should be measured such as module temperature, ambient temperature, irradiance, each current and voltage of components in real time.

2-wire PT100 temperature sensor is used for measuring PV module temperature in solar power plants. The PT100 was used in this project to measure the PV module temperature and also ambient temperature. This sensor can measure between $20^{\circ} \mathrm{C}$ and $100^{\circ} \mathrm{C}$. These type of sensors are called resistance temperature detectors (RTDs).

ACS712 current sensor is used for current measurement. It is hall effect-based linear current sensor that can measure up to $30 \mathrm{~A}$. Its operating temperature range of $-40^{\circ} \mathrm{C}$ to $85^{\circ} \mathrm{C}$. Analog to digital conversion needs to be done to read value.

A voltage divider is used to measure the voltage. It is is a simple circuit which turns a large voltage into a smaller one. Using just two series resistors and an input voltage, an output voltage that is a fraction of the input can be created. Thus, the voltage can be measured easily. Voltage dividers are one of the most fundamental circuits in electronics. Analog to digital conversion needs to be done to read value.

Figure 2: PV Module Measurements

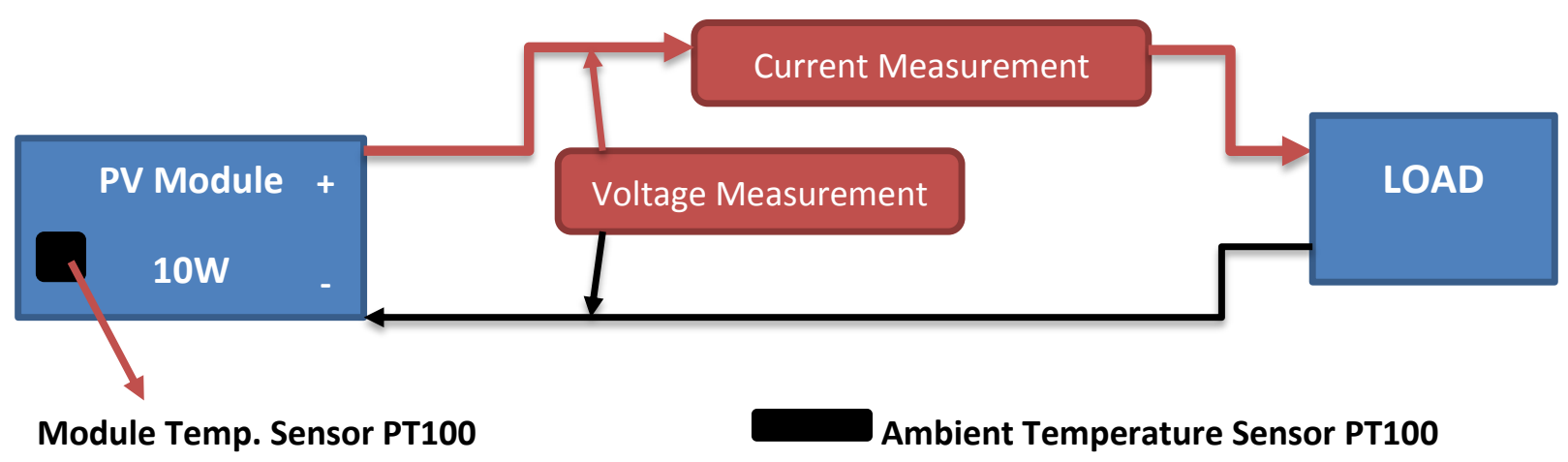


Tests are being done on 10W PV module. And also $25 \mathrm{~W}$ and $11 \mathrm{~W}$ aluminum and stone resistors are used as the load. To get that precision and accuracy out of PT100 RTD an amplifier that is designed to read the low resistance needs to be used. This situation also applies to the pryranometer.

Figure 3: Data Collection from the Sensors

\section{ALL SENSORS}

\section{End Device}

Sensors connected to the microcontroller board measure data. This data is processed on the microcontroller and the wireless communication module is ready for transmission.

\subsubsection{Data Processing}

Arduino UNO was used as a end device board nearby the PV module and sensors to collect and process sensor information. It is a microcontroller board based on the ATmega328P. It has 14 digital input/output pins (of which 6 can be used as PWM outputs), 6 analog inputs, a $16 \mathrm{MHz}$ quartz crystal, a USB connection, a power jack, an ICSP header and a reset button.

ACS712 required for current measurement is connected in series to the output of the photovoltaic module. The data output pin of the sensor is connected to the analog input of the Arduino. To get a better measurement, 150 samples are taken and the average of all is taken afterwards.

A voltage divider is made using resistors of $30 \mathrm{k}$ and $7.5 \mathrm{k}$. So that voltages in the range of $0-25 \mathrm{v}$ can be easily measured. The voltage divider output is connected to the analog input of the Arduino. The reference voltage was taken as 5 volts and the necessary operations were performed.

The output voltage of the PT100 RTD sensors is low and the amplifier board has been purchased to increase the output voltage. This card enhances the output signal of the sensor so that it allows precise measurement on the Arduino. The output of the amplifier board is directly connected to the digital input of the Arduino.

Arduino Mega 2560 was used as a coordinator board nearby the modem. It is a microcontroller board based on the ATmega2560. It has 54 digital input/output pins (of which 15 can be used as PWM outputs), 16 analog inputs, 4 UARTs (hardware serial ports), a $16 \mathrm{MHz}$ crystal oscillator, a USB connection, a power jack, an ICSP header, and a reset button. Arduino Mega 2560 is preferred as a coordinator because the coordinator side needs much more capacity and RAM than the end device side. In addition, the data received from the end device is transferred through the Ethernet module on the Mega 2560. That Ethernet module has own SD Card module. So when the internet connection is interrupted, SD Card steps in and records the non-transmitted data.

\subsubsection{Wireless Communication}

ZigBee is a low-power wireless mesh network standard operating in the $2.4 \mathrm{GHz}$ range. In this project, XBee modules were used to provide wireless data transmission. These modules are designed for a variety of uses, ranging from ZigBee to highthroughput, low latency applications. The XBee modules were engineered to meet IEEE 802.15.4 standards and support the unique needs of low-cost, low-power wireless sensor networks. The modules require minimal power and provide reliable delivery of data between devices. XBee used in this Project has $1.6 \mathrm{~km}$ outdoor data transmission range.

The most important reasons for choosing ZigBee in this project are; It supports IOT, provides energy efficiency and is reliable and scalable. ZigBee provides seamless interoperability among the widest range of smart devices related to home automation, energy management, and retail. ZigBee and ZigBee Pro consume 1/10,000th of the energy required by a Wi-Fi network. ZigBee is scalable, as it supports networks of thousands of nodes. Due to the use of security mechanisms like AES128 encryption devices, along with network keys and frame counters, it is also one of the most secure devices out there.

Table 1: Comparison of the WiFi, Bluetooth and ZigBee Protocols

\begin{tabular}{|l|c|c|c|}
\hline Category & WiFi & Bluetooth & ZigBee \\
\hline Underlying Standard & $802.11 . \mathrm{b}$ & 802.15 .1 & 802.15 .4 \\
\hline Range (meters) & $1-100$ & $1-10+$ & $1-100+$ \\
\hline Data Rate & 11 and 54 Mbits/s & $1 \mathrm{Mbit} / \mathrm{s}$ & 20,40 and $250 \mathrm{kbits} / \mathrm{s}$ \\
\hline Power Consumption & High & Low & Very Low \\
\hline Frequency & $2.4 \mathrm{and} 5 \mathrm{GHz}$ & $2.4 \mathrm{GHz}$ & $868 \mathrm{MHz}, 916 \mathrm{MHz}, 2.4 \mathrm{GHz}$ \\
\hline Network Nodes & 50 & 8 & 65535 \\
\hline Security & SSID & $64 \mathrm{bit}, 128 \mathrm{bit}$ & $128 \mathrm{bit}$ AES \\
\hline Integration Level \& Reliability & Normal & High & High \\
\hline
\end{tabular}




\begin{tabular}{|l|c|c|c|}
\hline Cost of Terminal Unit & High & Low & Low \\
\hline Prime Cost & Normal & Low & Low \\
\hline Optimized for & Speed & Low Cost, Convenience & $\begin{array}{c}\text { Reliability, Low Power } \\
\text { Consumption, Low Cost, } \\
\text { Scalability }\end{array}$ \\
\hline Typical Applications & $\begin{array}{c}\text { Wireless Local Area } \\
\text { Network (WLAN) } \\
\text { connectivity, broadband } \\
\text { internet, security } \\
\text { cameras }\end{array}$ & $\begin{array}{c}\text { Inter-device wireless } \\
\text { connectivity, e.g., } \\
\text { phones, PDAs, laptops, } \\
\text { headsets, cameras, } \\
\text { serial cable } \\
\text { replacements }\end{array}$ & $\begin{array}{c}\text { Industrial control and } \\
\text { monitoring, sensor } \\
\text { networks, building } \\
\text { automation, toys }\end{array}$ \\
\hline
\end{tabular}

The end device and the coordinator have their own XBee devices. The end device takes measurements every 2 minutes according to IEC standards and transmits the stored data wirelessly to the coordinator device. Moreover, thanks to continuous control, internet connection, wireless communication line and sensors are kept under control. The warnings are displayed on the LCD screen.

\subsection{Monitoring Dashboard}

The cloud hosting service was purchased to record the data of this system. Cloud hosting services provide hosting for websites on virtual servers that pull their computing resource from extensive underlying networks of physical web servers. Broadly speaking the client can tap into their service as much as they need, depending on the demands of their website, and they will only pay for what they use. All these services have reliability, physical security, scalability and flexibility, utility style costing and responsive load balancing.

Figure 4: Admin Dashboard of the Project (solar.hakanbogan.com)

\section{HB SOLAR MONITORING}

\section{SYSTEM INFORMATION}

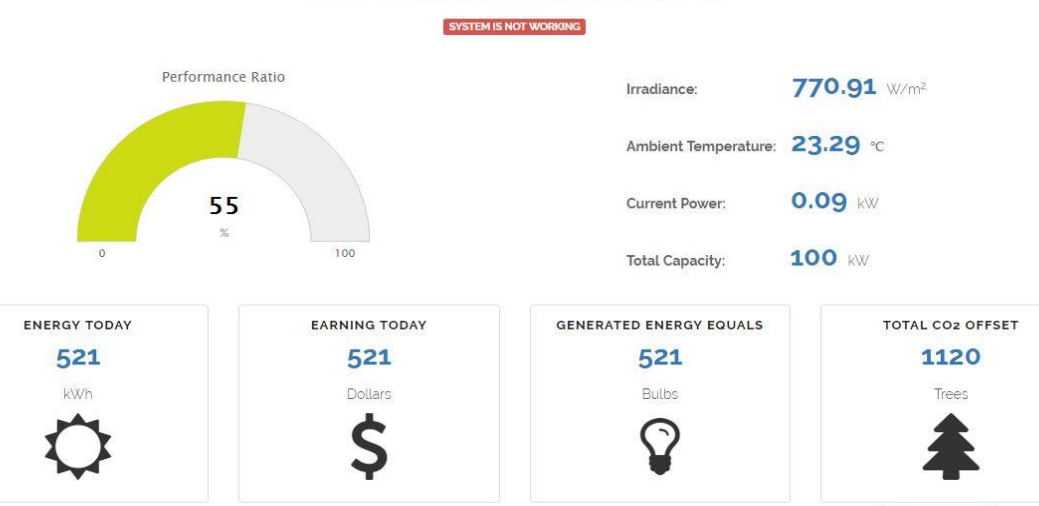

Monitoring dashboard is created from scratch with the bootstrap framework. Bootstrap was created at Twitter and it has become one of the most popular front-end frameworks and open source projects in the world. That monitoring dashboard has a completely responsive design. This means that it is compatible with all phones, tablets and computers. A login system is available and each investor has his / her own private page. Output of all data can be exported as xls, csv and pdf file from the web page. Thanks to this interface, investors can easily manage the photovoltaic power plant reports. 


\subsection{General Process}

Figure 5: Block Diagram of the Web-Based Wireless Monitoring System

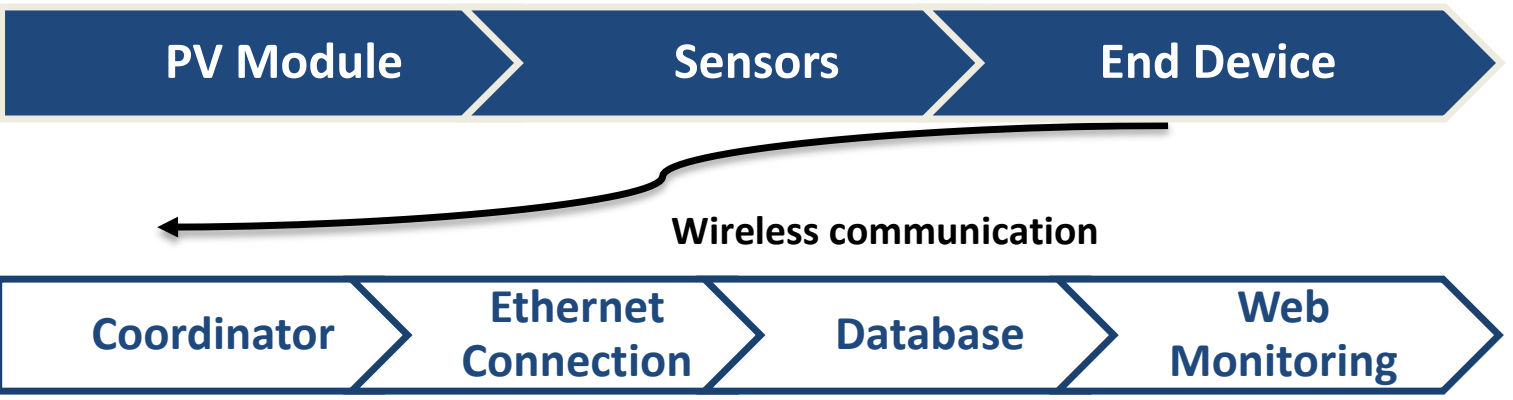

\section{FINDINGS AND DISCUSSIONS}

Figure 6: Wireless Communication between the Coordinator and End Device in the Serial Monitor

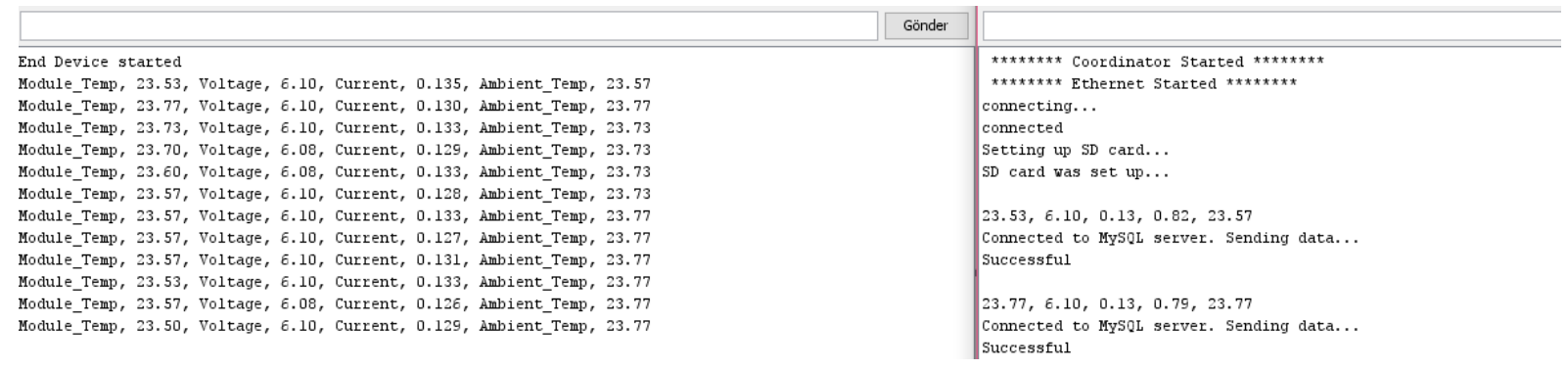

As a result of the tests, the system is able to transfer data in different weather conditions with no problems. Wireless transmission of data reaches $1.6 \mathrm{~km}$ (outdoor). The transmitted data was received by the receiving device with $100 \%$ and no data was lost. Within a variety of emergency scenarios, the device has continued to work successfully and record data. Thanks to the SD Card on the device, data loss is prevented.

\section{Figure 7: Data in the Database}

\begin{tabular}{|c|c|c|c|c|c|c|c|c|c|}
\hline 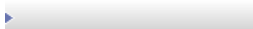 & $\nabla$ & id & timeStamp & temperature & voltage & current & power & irradiation & amb_temperature \\
\hline Düzenle 곡ㅊ Kopyala & $\Theta$ Sil & 18599 & 2017-04-20 20:42:09 & 23.4 & 6.64 & 0.15 & 0.97 & 0 & 23.6 \\
\hline Düzenle 감 Kopyala & $\ominus$ Sil & 18600 & $2017-04-20 \quad 20: 43: 56$ & 23.43 & 6.64 & 0.14 & 0.95 & 0 & 23.57 \\
\hline Düzenle 함 Kopyala & (-) Sil & 18601 & $2017-04-20 \quad 20: 47: 56$ & 23.36 & 6.64 & 0.14 & 0.93 & 0 & 23.53 \\
\hline Düzenle 고- & $\ominus$ Sil & 18602 & $2017-04-20 \quad 20: 49: 56$ & 23.36 & 6.64 & 0.14 & 0.92 & 0 & 23.57 \\
\hline Düzenle 괌 Kopyala & $\ominus$ Sil & 18603 & $2017-04-20 \quad 20: 51: 56$ & 23.4 & 6.64 & 0.14 & 0.94 & 0 & 23.57 \\
\hline Düzenle 곰 Kopyala & $\ominus$ Sil & 18604 & $2017-04-20 \quad 20: 53: 56$ & 23.23 & 6.64 & 0.14 & 0.94 & 0 & 23.46 \\
\hline Düzenle 콜 Kopyala & $\ominus$ Sil & 18605 & 2017-04-20 20:56:02 & 23.33 & 6.64 & 0.14 & 0.93 & 0 & 23.46 \\
\hline Düzenle 감 Kopyala & $\ominus$ Sil & 18606 & $2017-04-20 \quad 20: 57: 56$ & 23.33 & 6.64 & 0.14 & 0.92 & 0 & 23.5 \\
\hline Düzenle 곡`́ Kopyala & (- Sil & 18607 & $2017-04-20 \quad 20: 59: 56$ & 23.4 & 6.64 & 0.15 & 0.97 & 0 & 23.53 \\
\hline Düzenle 글 Kopyala & $\ominus$ Sil & 18608 & 2017-04-20 21:01:56 & 23.5 & 6.64 & 0.14 & 0.94 & 0 & 23.7 \\
\hline Düzenle 콜 Kopyala & $\odot$ Sil & 18609 & 2017-04-20 21:03:56 & 23.6 & 6.64 & 0.13 & 0.88 & 0 & 23.67 \\
\hline Düzenle 고- Kopyala & $\ominus$ Sil & 18610 & 2017-04-20 21:05:56 & 23.53 & 6.64 & 0.15 & 0.97 & 0 & 23.63 \\
\hline Düzenle 골t Kopyala & $\odot$ Sil & 18611 & 2017-04-20 21:07:56 & 23.46 & 6.64 & 0.14 & 0.92 & 0 & 23.6 \\
\hline Düzenle 감 Kopyala & $\odot$ Sil & 18612 & 2017-04-20 21:09:57 & 23.4 & 6.64 & 0.14 & 0.96 & 0 & 23.57 \\
\hline Düzenle 굴t Kopyala & $\odot$ Sil & 18613 & 2017-04-20 21:12:03 & 23.36 & 6.64 & 0.14 & 0.94 & 0 & 23.57 \\
\hline Düzenle ż- Kopyala & (-) Sil & 18614 & $2017-04-20 \quad 21: 13: 57$ & 23.33 & 6.64 & 0.14 & 0.95 & 0 & 23.53 \\
\hline
\end{tabular}


Figure 8: Data Table and Temperature Chart of the Tests

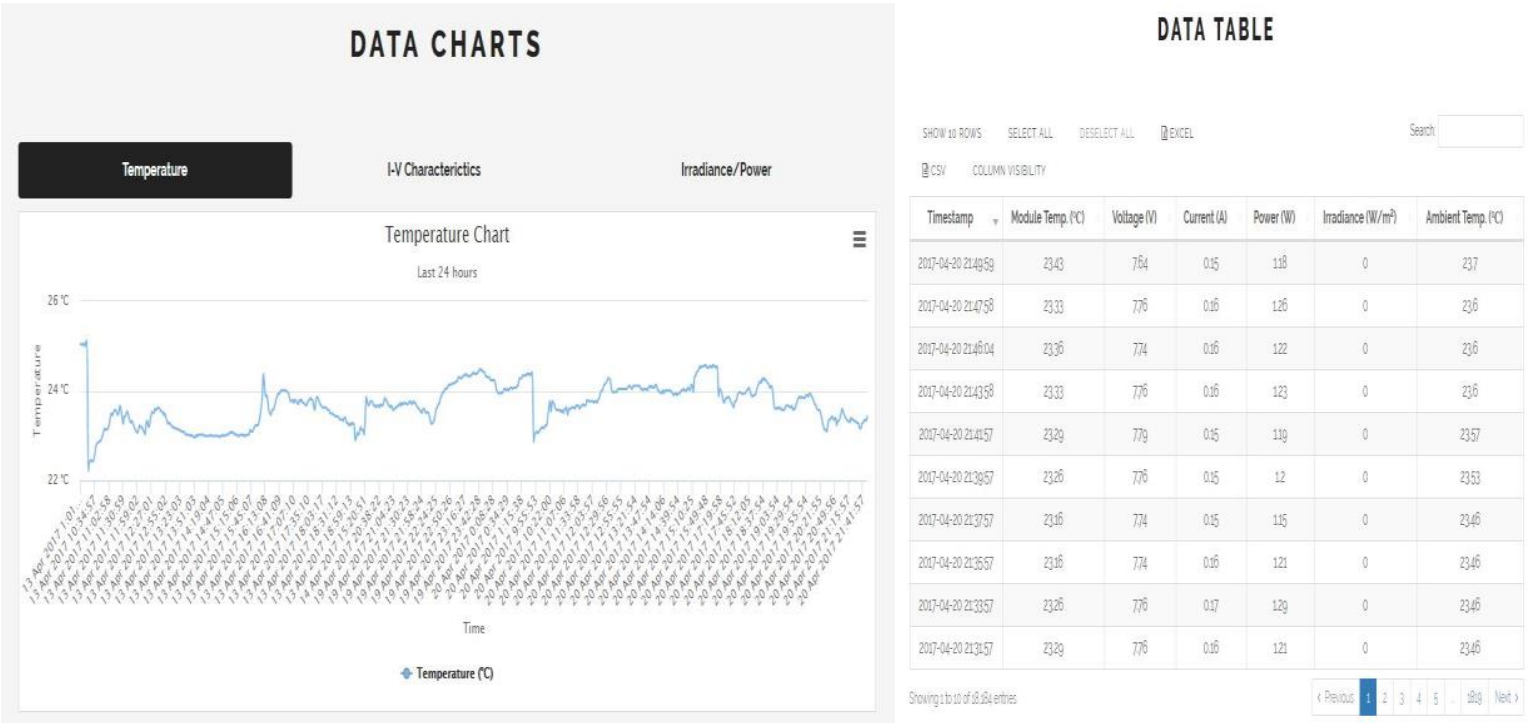

All the data received by the coordinator is sent to the hakanbogan.com database via the modem to which the ethernet cable is connected. Very large data can be stored in the database. So there is no problem of data logging for many years. More than 18,000 measurements were made in the tests and the data of each was recorded with no problems. Data from any date can be exported as xls, csv or pdf through the monitoring dashboard. It has also been tested.

Figure 9: End Device and Coordinator

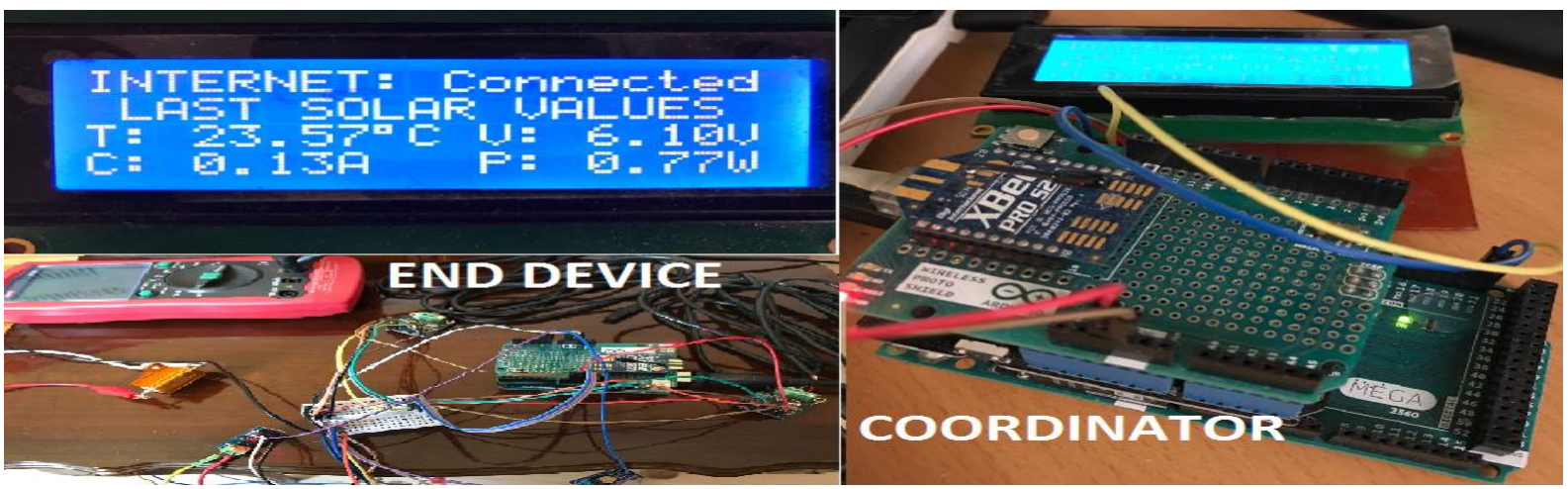

Figure 10:. Current Draws of the End Device and the Coordinator

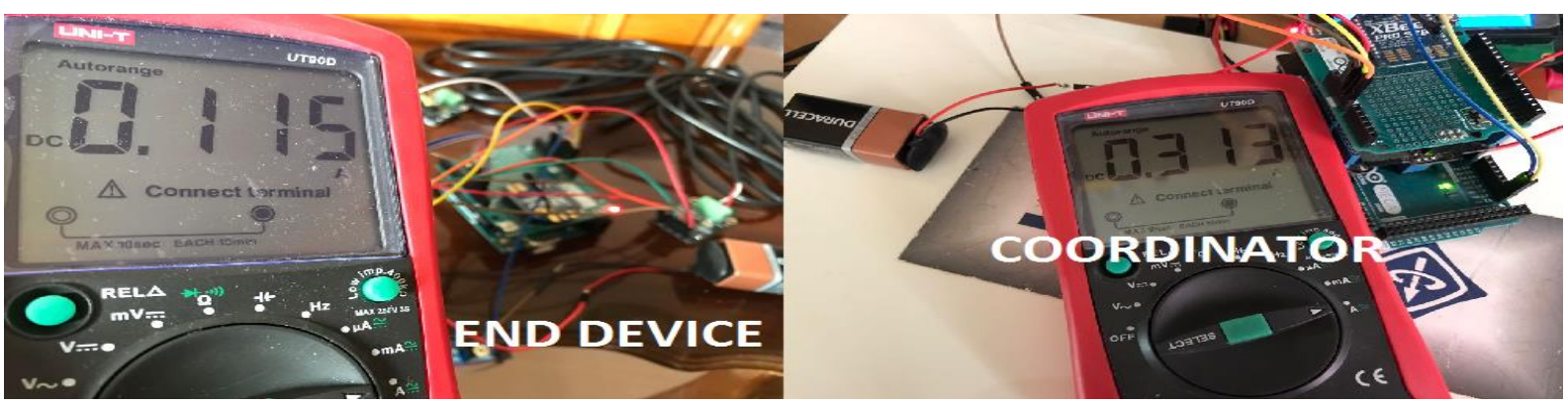


As seen in Fig. 10, power consumption is very low. These current values were measured using a 9v battery. The following calculations related to monthly electricity consumption can be made.

Battery has $8.32 \mathrm{~V}$ while the end device is connected and has $7.47 \mathrm{~V}$ while the coordinator is connected.

End Device: $0.115 \mathrm{~A} \times 8.32 \mathrm{~V}=0.957 \mathrm{~W}$ (DC)

Coordinator: $0.313 \mathrm{~A} \times 7.47 \mathrm{~V}=2.338 \mathrm{~W}(\mathrm{DC})$

$0.957 \mathrm{~W} \times 24 \mathrm{~h}=22.963 \mathrm{Wh} /$ day (DC)

$2.338 \mathrm{~W} \times 24 \mathrm{~h}=56.115 \mathrm{Wh} /$ day $(\mathrm{DC})$

$22.963 \mathrm{Wh} /$ day $\times 30=688.896 \mathrm{Wh} / \mathrm{month}(\mathrm{DC})$

$56.115 \mathrm{Wh} /$ day $\times 30=1,683.4392 \mathrm{Wh} /$ month (DC)

Total consumption: $(688.896)+(1,683.4392)=\mathbf{2 , 3 7 2 . 3 3 5 2 ~ W h / m o n t h}(D C)$

The photovoltaic array, pryranometer, anemometer (optional) measurements must also be added to these measurements for the device to be adapted to real life. In order to further reduce power consumption and production cost, it is necessary to design the microcontroller card from scratch. Then a suitable box must be designed for the device.

\section{CONCLUSION}

Zigbee based wireless online monitoring system for photovoltaic power systems was developed and will continue to be developed. The system design features easy-to-obtain hardware and free software, making it accessible to any researcher. IEC 61724 standards were taken into consideration while the system was being developed. In the tests, 10W solar panel, $25 \mathrm{~W}$ aluminum resistors, temperature, voltage and current sensors were used as photovoltaic equipment. In particular, it has been tested to ensure that the software used on the device and all electronic equipment work properly with each other. The system transmits each measured data wirelessly without any loss. The web page also displays all data without any problems. All data can be kept in the database. In emergency scenarios, data loss is prevented by recording the data to the SD card with continuous checks. Power consumption is also noticeably low. As a result, the system is working successfully.

In the future, this system needs to be developed. One of the most difficult stages to measure the pyranometer. Studies are running to make precise measurement of the pyranometer. When theoretically every stage is completed, the experiments will continue at a real photovoltaic power plant for a long time. Moreover, in the future, an unique card design will be made instead of Arduino. The device software will be updated with an emphasis on low power consumption. Thus, the cost and power consumption of the product are planned to be further reduced. The design will be improved by designing a box suitable for the device. Monitoring dashboard will also be updated to make it more functional.

\section{REFERENCES}

IEC 61724, 1988, "Photovoltaic system performance monitoring guidelines for measurement, data exchange and analysis", International Electrotechnical Commission (IEC).

Shariff F., Rahim N. A. and Ping H. W., 2015, "Zigbee-based data acquisition system for online monitoring of grid-connected photovoltaic system", Expert Systems with Applications, vol. 42, no. 3, pp. 1730-1742.

Rosiek S., Batlles F.J., 2008, “A microcontroller-based data-acquisition system for meteorological station monitoring”, Energy Conversion and Management, vol. 49, no. 12, pp. 3746-3754.

Hu T., Zheng M., Tan J., Zhu L. and Miao W., 2015, “Intelligent photovoltaic monitoring based on solar irradiance big data and wireless sensor networks", Ad Hoc Networks, vol. 35, pp. 127-136.

Hua Jianfeng, Lin Xinfan, Xu Liangfei, Li Jianqiu and Ouyang Minggao, 2009, “Bluetooth wireless monitoring, diagnosis and calibration interface for control system of fuel cell bus in Olympic demonstration", Journal of Power Sources, vol. 186, pp. 478-484.

Zahurul S., Mariun N., Grozescu I. V., Tsuyoshi H., Mitani Y., Othman M. L., Hizam H. and Abidin I. Z., 2015, "Future strategic plan analysis for integrating distributed renewable generation tos mart grid through wireless sensor network: Malaysia prospect", Renewable and Sustainable Energy Reviews, vol. 53, pp. 978-992.

Fuentes M., Vivar M., Burgos J.M., Aguilera J. and Vacas J.A., 2014, “Design of an accurate, low-cost autonomous data logger for PV system monitoring using Arduino that complies with IEC standards", Solar Energy Materials \& Solar Cells, vol. 130, pp. 529-543.

Meliones A., Apostolacos S. and Nouvaki A., 2014, "A web-based three-tier control and monitoring application for integrated facility management of photovoltaic systems", Applied Computing and Informatics, vol. 10, pp. 14-37.

Papageorgas P., Piromalis D., Antonakoglou K., Vokas G., Tseles D. and Arvanitis K. G., 2013, "Smart solar panels: in-situ monitoring of photovoltaic panels based on wired and wireless sensor networks", Energy Procedia, vol. 36, pp. 535-545. 
Almaliky A. (2014). Development of wireless monitoring system for photovoltaic panels. Retrieved from http://researcharchive.wintec.ac.nz/3362/

Katsioulis V. (2011). Design of a wireless monitoring system based on the zigbee protocol for photovoltaic systems (Doctoral dissertation). Retrieved from http://bura.brunel.ac.uk/handle/2438/5189

Batista N.C., Melicio R., Matias J.C.O. and Catalao J.P.S., 2013, "Photovoltaic and wind energy systems monitoring and building/home energy management using zigbee devices within a smart grid", Energy, vol. 49, pp. 306-315.

Andreoni M., Mantinan F. G., and Molina M.G. (2012). Implementation of wireless remote monitoring and control of solar photovoltaic (PV) system, Latin America Conference and Exposition, doi: 10.1109/TDC-LA.2012.6319050

Gagliarducci M., Lampasi D.A. and Podesta L., 2007, “GSM-based monitoring and control of photovoltaic power generation”, Measurement, vol. 40, 314-321.

Ayompe L.M., Duffy A., McCormack S.J. and Conlon M., 2011, “Measured Performance of a 1.72 kW Rooftop Grid Connected Photovoltaic System in Ireland", Energy Conversion and Management, vol. 52, pp. 816-825.

Woyte A., Richter M., Moser D., Mau S., Reich N. and Jahn U., 2013, “Monitoring of photovoltaic systems: good practices and systematic analysis", The $28^{\text {th }}$ European PV Solar Energy Conference and Exhibition, doi: 10.4229/28thEUPVSEC2013-5CO.6.1

Philipps S. and Warmuth W., (2016). Photovoltaics Report. Retrieved from Fraunhofer ISE Website:

https://www.ise.fraunhofer.de/content/dam/ise/de/documents/publications/studies/Photovoltaics-Report.pdf

Krauter S.C.W. and Depping T., 2004, "Remote PV-system monitored via satellite”, Solar Energy Materials \& Solar Cells, vol. 82, pp. 139150.

Anwaria M., Domb M.M. and Rashid M.I.M., 2011, “Small Scale PV Monitoring System Software Design”, Energy Procedia, vol. 12, pp. 586592.

Xiaolia X. and Huanb W., 2011, "The Wireless Sensor Network Construction of the Photovoltaic Power System--ZigBee", Procedia Engineering, vol. 15, pp. 2511-2515.

Katsioulis V., Karapidakis E., Hadjinicolaou M., and Tsikalakis A. (2011). Wireless Monitoring and Remote Control of PV Systems Based on the ZigBee Protocol, IFIP Advances in Information and Communication Technology, doi: 10.1007/978-3-642-19170-1_32

Rapacioli G. (n.d.). Reti wireless - Zigbee. Retrieved from http://www.swappa.it/wiki/Uni/RW-13Aprile

Why Zigbee is the Fastest Growing Trend in Wireless Technology. (2016, July 7). Retrieved from https://www.technavio.com/blog/whyzigbee-fastest-growing-trend-wireless-technology

XBee and XBee Pro Zigbee (n.d.). Retrieved from https://www.digi.com/pdf/ds_xbee_zigbee.pdf

Güneş Enerji Santralleri (n.d.). Retrieved from http://www.enerjiatlasi.com/gunes/ 